\title{
Dissociation of Azo Dye-treated Heterochromatin and Release of Non-Histone Proteins*
}

(Received October 26, 1989)

\author{
Makoto Yoshimoto, Ryoji Shichita, Masayuki Shioyama and Shoji Hatano \\ (Department of Food and Science Technology, Faculty of Agriculture, \\ Kyushu University: 6-10-1, Hakozaki, Higashi-ku, Fukuoka, Japan)
}

\begin{abstract}
Amaranth (FD \& Red C No. 2) and Ponceau 3R stimulate in vitro RNA synthesis by causing the dissociation of chromatin in isolated rat-liver nuclei. To elucidate the mechanism of chromatin dissociation, the effect of amaranth on chromosomal proteins was examined using heterochromatin prepared from isolated rat-liver nuclei. The dissociation of amaranth-or Ponceau 3R-treated heterochromatin was confirmed by both solubility measurement and electron microscopy. Amaranth released nonspecific non-histone proteins and increase in its concentration resulted in the release of non-histone proteins with molecular weights of 17.5 , 25 , and 31 kilodaltons in addition to the nonspecific non-histone proteins. These non-histone proteins were presumed to be high mobility group (HMG) proteins from their behavior on SDS-electrophoresis. On the other hand, no release of histone was observed in these experiments.
\end{abstract}

Key words: non-histone protein; amaranth; heterochromatin; Ponceau 3R; Ssunset Yellow FCF; chromatin dissociation; histone; high mobility group (HMG) proteins

\section{Introduction}

DNA in eukaryotic cells is extensively folded in the nucleosome, which is itself involved in higher-order structures. Changes in chromatin conformation are strongly correlated with regulation of gene expression ${ }^{11}$.

In the previous paper of this series, we have reported that amaranth (FD \& Red C No. 2) and Ponceau 3R cause the dissociation of heterochromatin and stimulate in vitro RNA synthesis in isolated rat-liver nuclei ${ }^{2}$, suggesting the possibility that these azo dyes might affect gene expression in eukaryotic cells. However, it is unclear what kind of chromosomal protein is responsible for the dissociation of chromatin by the azo dyes. In trying to identify the mechanism of action of the azo dyes on chromosomal proteins we focused our attention on morphologically condensed chromatin, heterochromatin, since the dissociation of heterochromatin by the

\footnotetext{
* Paper No. 10 of the series "The Effect of Tar Dyes on RNA Synthesis".
}

azo dyes is obvious in isolated rat-liver nuclei ${ }^{2)}$ and is accompanied with a readily observable solubility change ${ }^{3}$. We assumed that any change in chromatin organization, if it occurs, should be more evident in the heterochromatin fraction than in the total chromatin, nuclei.

This report confirms the dissociation in azo dye-treated heterochromatin and the release of chromosomal protein from heterochromatin treated with amaranth.

\section{Materials and Methods}

\section{Materials}

Amaranth, Ponceau 3R and Sunset Yellow FCF were obtained from the National Institute of Hygienic Sciences in Japan. Sunset Yellow FCF was used as an azo dye which does not stimulate RNA synthesis in isolated rat-liver nucle $i^{4)}$. Their structures are given in Fig. 1. Male Wistar rats weighing approximately $200 \mathrm{~g}$ were obtained from Seiwa Experimental Animals.

Isolation of rat-liver nuclei

Nuclei were prepared from rat liver as de- 
<smiles>O=[N+]([O-])c1ccc(N=Nc2c(O)ccc3cc([N+](=O)[O-])ccc23)cc1</smiles>

(1)<smiles>Cc1cc(C)c(N=Nc2c(O)c(S(=O)(=O)O)cc3cc(S(=O)(=O)O[Na])ccc23)cc1C</smiles>

(II)

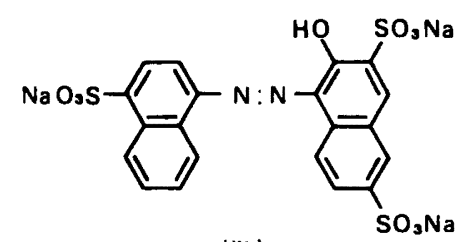

(III)

Fig. 1. Structural formulae for azo dyes

(I), Sunset Yellow FCF; (II), Ponceau 3R; (III), Amaranth

scribed previously ${ }^{4}$. All procedures were performed at $4^{\circ} \mathrm{C}$ unless otherwise specified. Livers were weighed and minced finely with scissors in two volumes of the buffer and were homog. enized with a Teflon pestle. The homogenate was filtered through four layers of gauze and the filtrate was mixed with two volumes of a concentrated sucrose buffer containing $0.05 \mathrm{M}$ Tris-hydrochloric acid ( $\mathrm{pH} 7.5$ ), $2.3 \mathrm{M}$ sucrose, $25 \mathrm{~m} M$ potassium chloride and $5 \mathrm{mM}$ magnesium chloride. The mixture was layered on $15 \mathrm{ml}$ of concentrated sucrose buffer and the discontinuous gradients were centrifuged for $50 \mathrm{~min}$ at $40,000 \times g$ in a Hitachi RP-50 rotor. This nuclear pellet was resuspended in $0.01 M$ Trishydrochloric acid (pH 8.3), $0.25 M$ sucrose, 25 $\mathrm{m} M$ potassium chloride and $5 \mathrm{~m} M$ magnesium chloride by gentle homogenization. The homogenate was centrifuged for $10 \mathrm{~min}$ at $1000 \times \mathrm{g}$ to remove the concentrated sucrose. Protein concentration was estimated by the method of Bradford ${ }^{5)}$. Bovine serum albumin was used as the standard.

Preparation of rat-liver heterochromatin

Heterochromatin was prepared from the puri- fied nuclei by the method of Comings et al. ${ }^{6}$. The nuclei were then washed five times in NMCT buffer $(0.15 M$ sodium chloride, $0.5 \mathrm{mM}$ magnesium chloride, $0.5 \mathrm{~m} M$ calcium chloride, $50 \mathrm{~m} M$ Tris-hydrochloric acid, $\mathrm{pH} 7.5$ ) at $1000 \times$ $g$ for $5 \mathrm{~min}$. The nuclei were resuspended in 50 $\mathrm{ml}$ of NMCT buffer and sonicated at setting No. 7 of a Branson Model 575 sonicator for $30 \mathrm{sec}$. This sonicate was distributed into four $12 \mathrm{ml}$ thick-walled tubes and centrifuged at $400 \times \mathrm{g}$ for $10 \mathrm{~min}$; the pellet and supernatant were separated. The $400 \times g$ pellet was resuspended in 25 $\mathrm{ml}$ of NMCT buffer, resonicated for $20 \mathrm{sec}$ and recentrifuged at $400 \times \mathrm{g}$ for $10 \mathrm{~min}$. The $400 \times \mathrm{g}$ pellet was taken as heterochromatin on the basis of solubility, electron microscopy and nuclear protein analysis.

Solubilization of azo dye-treated heterochromatin

The solubility of heterochromatin was determined by measuring the DNA content in the precipitate after centrifugation of the reaction mixture at $400 \times \mathrm{g}$ for $10 \mathrm{~min}$. A heterochromatin sample ( $30 A_{260}$ units) was treated at $4^{\circ} \mathrm{C}$ for $20 \mathrm{~min}$ with the desired amount of azo dye in NMCT buffer. The solution was centrifuged at $400 \times g$ for $10 \mathrm{~min}$ and the supernatant was discarded. The resulting precipitate was wet-ashed in perchloric acid and the phosphorus content was determined.

\section{Electron microscopy}

Azo dye-treated or -untreated heterochromatin was suspended in NMCT buffer, and 25\% glutaraldehyde was added to give a final concentration of $2.5 \%$. After fixation for $1 \mathrm{hr}$ at $0^{\circ} \mathrm{C}$, the suspension was centrifuged at $10,000 \times g$ for $10 \mathrm{~min}$. The pellets were postfixed in $1 \%$ osmic acid for $1 \mathrm{hr}$, dehydrated through a series of acetone washes, and embedded in Epon 812. Sections were stained with uranyl acetate and lead citrate, and examined in a Hitachi $\mathrm{H}-500$ electron microscope at an accelerating voltage of $75 \mathrm{kV}$.

Release of chromosomal protein from azo dyetreated heterochromatin

Heterochromatin samples (17 $A_{260}$ units) were mixed with various amounts of azo dyes for 20 $\min$ at $4^{\circ} \mathrm{C}$. After centrifugation at $100,000 \times g$ for $22 \mathrm{hr}$, the supernatant $(9 \mathrm{ml})$ was concentrated by ultrafiltration with a Centricut (type U-10, 10,000 MW cut-off), dialyzed against $1 \mathrm{mM}$ Tris- 
hydrochloric acid (pH 7.5) containing $0.1 \mathrm{mM}$ PMSF at $4^{\circ} \mathrm{C}$ overnight and lyophilized. The lyophilized samples were dissolved in $100 \mu$ l of the solubilizing solution for SDS-polyacrylamide gel electrophoresis and $10 \mu \mathrm{l}$ was applied to the gel as released nuclear protein. The $100,000 \times g$ precipitate was directly dissolved in the solubilizing solution and subjected to SDSpolyacrylamide gel electrophoresis for the analysis of histone proteins.

\section{Analytical gel electrophoresis}

Chromosomal proteins were analyzed in $18 \%$ polyacrylamide gel containing $0.1 \%$ SDS in Trisglycine buffer utilizing a 9-cm separating gel in conjunction with a $1-\mathrm{cm} 3 \%$ acrylamide stacking gel as described by Laemmli ${ }^{7}$. Before application, the chromosomal protein samples were dissolved in the solubilizing solution. To ensure complete solubilization, the protein samples were heated at $100^{\circ} \mathrm{C}$ for $3 \mathrm{~min}$. Dissolved chromosomal proteins were applied to gels under the reservoir buffer of $25 \mathrm{~m} M$ Tris- $0.15 \mathrm{M}$ glycine ( $\mathrm{pH}$ 8.3). Electrophoresis carried out at a constant current of $1.0 \mathrm{~mA} / \mathrm{gel}$, until the tracking dye entered the separation gel, after which a constant $20 \mathrm{~mA}$ was applied until the tracking dye reached $5 \mathrm{~mm}$ from the bottom of each gel. Gels containing histone proteins were stained overnight in $0.05 \%$ Coomassie brilliant blue R250 or for released nuclear proteins with silver stain. Approximate molecular weight was determined using the following protein standards: cytochrome $c$ monomer $(12,400)$, dimer $(24,800)$, trimer $(37,200)$, tetramer $(49,600)$, and hexamer $(74,400)$.

\section{Extraction of high mobility group proteins}

The high mobility group (HMG) proteins were extracted from isolated rat-liver nuclei by the method of Inoue et al. ${ }^{8}$. The nuclei were suspended in $10 \mathrm{ml}$ of $5 \mathrm{mM}$ sodium phosphate buffer (pH 6.8) containing $0.35 \mathrm{M}$ sodium chloride, and $0.25 \mathrm{mM}$ PMSF and homogenized using a loose-fitting Teflon-glass homogenizer with 40 strokes by hand. The homogenate was centrifuged, and the supernatant was adjusted to $5 \%$ perchloric acid concentration by adding a $60 \%$ solution. After cerntrifugation, 7 volumes of cold acetone was added to the supernatant and the mixture was stirred slowly for $1 \mathrm{hr}$ at $0^{\circ} \mathrm{C}$ and then kept at $-20^{\circ} \mathrm{C}$ for $15 \mathrm{hr}$. The

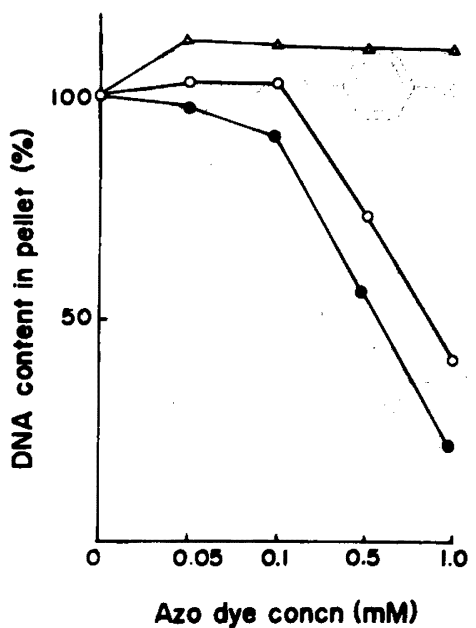

Fig. 2. Effect of azo dyes on the solubility of rat-liver heterochromatin

$\triangle$. Sunset Yellow FCF; $O$, Amaranth;

. Ponceau 3R.

precipitate was collected by centrifugation, washed with acetone and dried.

\section{Results}

Effect of azo dyes on solubility of heterochromatin

We noticed in this study that heterochromatin was solubilized in the presence of the azo dyes. Accordingly, the effect of azo dyes on the solubility of heterochromatin was investigated and the result is shown in Fig. 2. Heterochromatin samples were mixed with azo dye at a concentration of $0.0 .05,0.1 .0 .5$, or $1.0 \mathrm{mM}$. The solubility was determined by measuring the DNAcontent in the $400 \times g$ precipitate. Heterochromatin in the absence of azo dye was quan. titatively pelleted. When heterochromatin was treated with Ponceau $3 R$ at a concentration of 0.5 or $1.0 \mathrm{mM}$, the DNA recovered in the precipitate amounted to about 60 or $20 \%$, respectively. The corresponding values of the amaranthtreated fraction were 70 and $40 \%$ at the same concentrations. The recovery of DNA was $100 \%$ at below $0.1 \mathrm{mM}$ amaranth and Ponceau 3R. Sunset Yellow FCF treatment had no effect on the solubility at any concentration tested.

Electron microscopic analysis of azo dye-untreated and -treated heterochromatin

We have already reported in the previous paper that amaranth and Ponceau $3 R$ affect the 


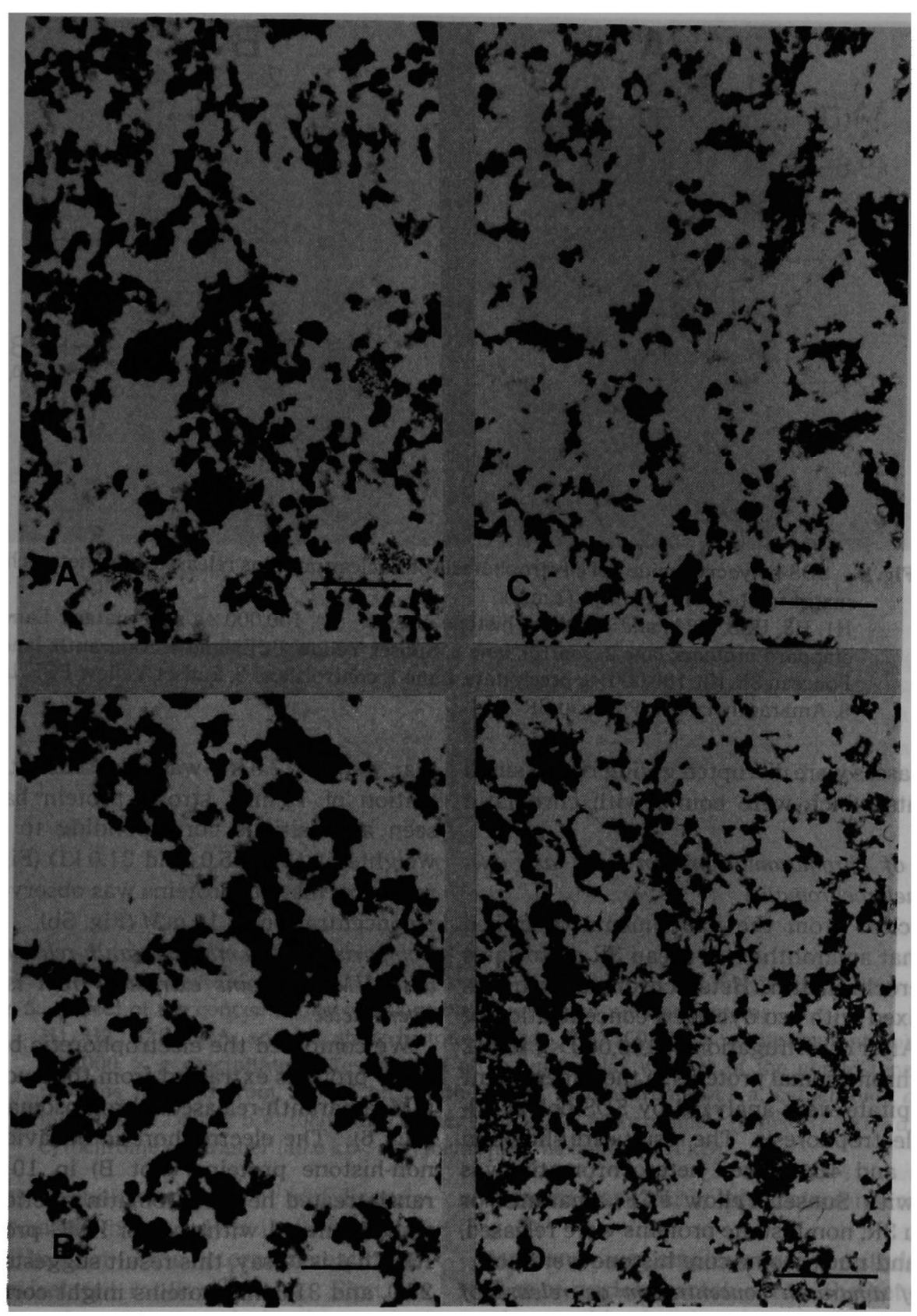

Fig. 3. Electron micrographs of rat-liver heterochromatin untreated or treated with azo dyes. (A), untreated; (B), Sunset Yellow FCF; (C), amaranth; (D), Ponceau 3R. Bars, $1 \mu \mathrm{m}$.

chromatin conformation in isolated-rat liver nuclei $^{2)}$. However, it is not apparent whether amaranth or Ponceau 3R dissociates heterochromatin prepared from isolated rat-liver nuclei. Electron micrographs of azo dye-untreated and
$1 \mathrm{~m} M$ Sunset Yellow FCF-treated heterochromatin are shown in Fig. $3 \mathrm{~A}$ and $3 \mathrm{~B}$. Heterochromatin was observed in condensed form. When heterochromatin was treated with $1 \mathrm{mM}$ amaranth (Fig. 3C) or Ponceau 3R (Fig. 3D), the 


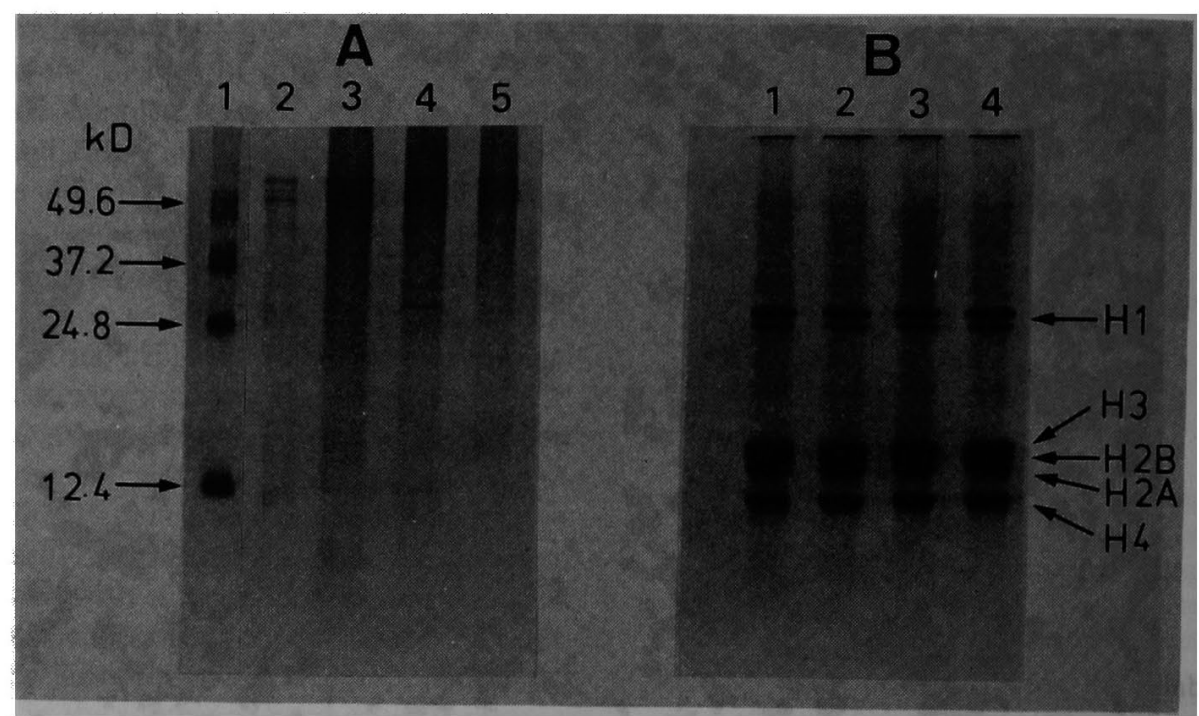

Fig. 4. SDS-polyacrylamide gel electrophoresis of nuclear proteins released from heterochromatin treated with azo dye $(1 \mathrm{mM})$.

H1, H3, H2B, H2A, and H4 show histone classes. (A), 100,000 $\times g$ supernatant; Lane 1, standard proteins; lane 2, control; lane 3, Sunset Yellow FCF; lane 4, Amaranth; lane 5, Ponceau 3R. (B), 100,000 $\times g$ precipitate. Lane 1, control; lane 2, Sunset Yellow FCF; lane 3, Amaranth; lane 4, Ponceau 3R

dense masses were disrupted giving rise to small fragments which were bound with chromatin fibrils.

Release of chromosomal protein from azo dyetreated heterochromatin

It is clear from the experiments described above that amaranth or Ponceau 3R dissociates the heterochromatin. Heterochromatin samples were mixed with azo dyes at a concentration of $1 \mathrm{~m} M$. After centrifugation at $100,000 \times \mathrm{g}$ for 22 $\mathrm{hr}$, the chromosomal proteins in the supernatant or precipitate were analyzed by SDS-polyacrylamide electrophoresis. The results are shown in Fig. 4A and 4B. When heterochromatin was mixed with Sunset Yellow FCF, amaranth or Ponceau 3R, non-histone proteins were released, but $\mathrm{Hl}$ and nucleosome-core histone were not.

Effect of amaranth concentration on release of non-histone proteins from heterochromatin

As no marked release of non-histone proteins was observed at a dye concentration of $1 \mathrm{mM}$, we increased the concentration of amaranth. The result is shown in Fig. 5a. Increase in amaranth concentration prolonged the release of non-histone proteins from heterochromatin. At a concentration of $5 \mathrm{mM}$, a protein of molec- ular weight $17.5 \mathrm{kD}$ was released. At a concentration of $10 \mathrm{mM}$, strong protein bands were seen at positions corresponding to molecular weights of $17.5,25.0$, and $31.0 \mathrm{kD}$ (Fig. $5 \mathrm{c}$ ). No release of histone proteins was observed even at a concentration of $10 \mathrm{mM}$ (Fig. $5 \mathrm{~b}$ ).

Comparison of $10 \mathrm{mM}$ amaranth-released proteins with $H M G$ proteins extracted from isolated rat liver nuclei

We compared the electrophoretic behavior of HMG proteins extracted from the nuclei and 10 $\mathrm{m} M$ amaranth-released chromosomal proteins (Fig. 6). The electrophoretic behavior of three non-histone proteins (slot B) in $10 \mathrm{mM}$ amaranth-treated heterochromatin fraction appears to be identical with that of HMG proteins (slot A). That is to say, this result suggests that 17.5 , 25.0 , and $31.0 \mathrm{kD}$ proteins might correspond to HMG 17, HMG 14 and HMG 2 proteins, respectively.

\section{Discussion}

Many investigators have reported differences in density ${ }^{9}$, solubility ${ }^{3)}$, and nuclease susceptibility $^{10}$ between template-active and template-inactive chromatin. We also reported 


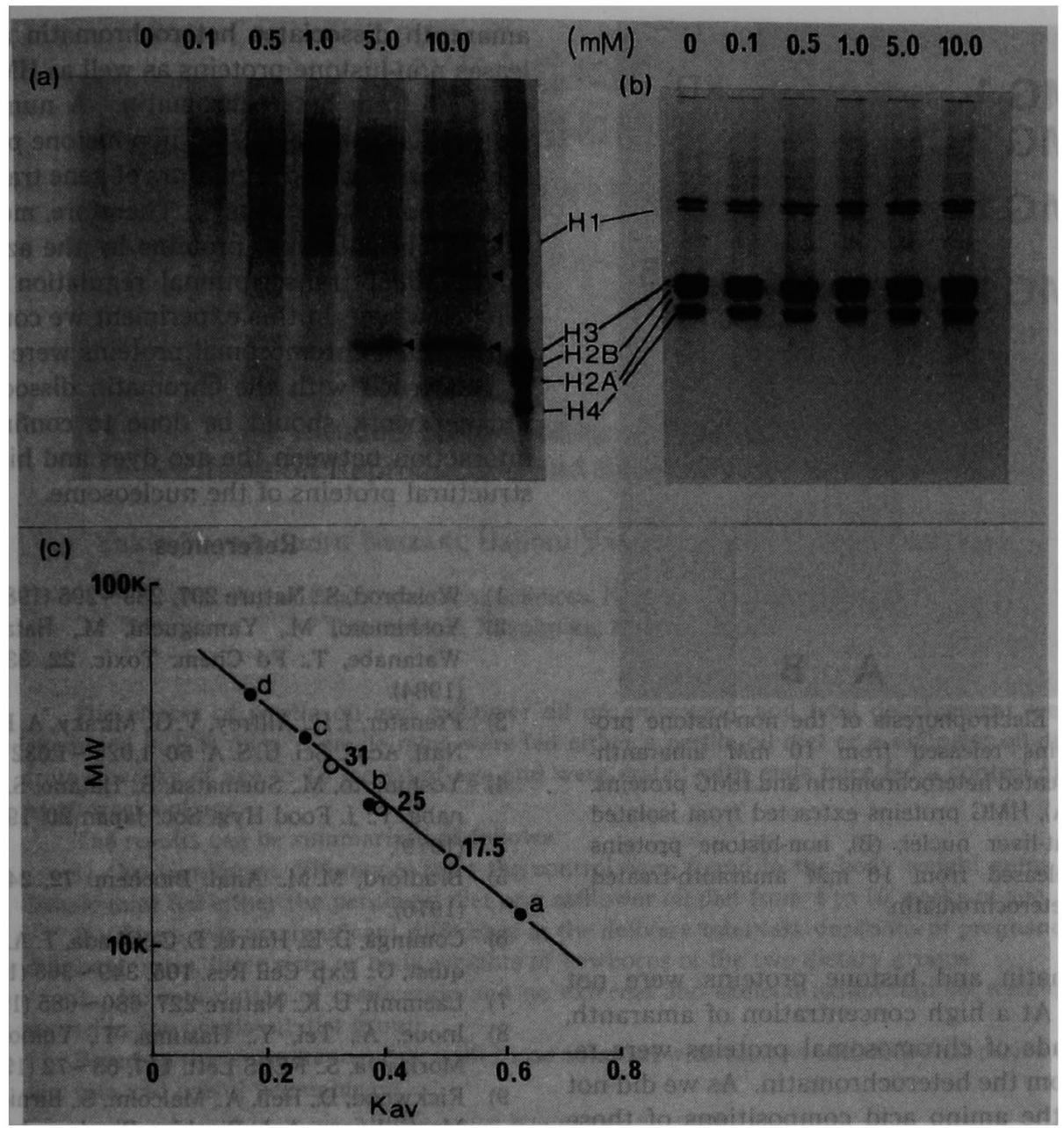

Fig. 5. Effect of the concentration of amaranth on release of nuclear proteins

H1, H3, H2B, H2A, and H4 show histone classes. (a), 100,000 $\times$ g supernatant; (b), $100,000 \times g$ precipitate; (c), estimation of the molecular weights of the non-histone proteins released from $10 \mathrm{mM}$ amaranth-treated heterochromatin. a, cytochrome $c$ monomer (12.4 kD); b, cytochrome $c$ dimer $(24.8 \mathrm{kD})$; c, cy tochrome $c$ trimer $(37.2 \mathrm{kD})$; d, cytochrome $c$ tetramer $(49.6 \mathrm{kD})$; e, cy tochrome $c$ hexamer $(74.4 \mathrm{kD})$.

the high susceptibility to DNase $\mathrm{I}^{4)}$ and dissociation of chromatin by azo dyes in isolated ratliver nuclei, but not in the heterochromatin prepared from isolated rat-liver nuclei. First, we planned to confirm the dissociation in azo dyetreated heterochromatin. The change in structure of azo dye-treated heterochromatin was assessed in terms of the solubility and by electron microscopy. Modification of heterochromatin with amaranth or Ponceau $3 \mathrm{R}$ was accompanied with progressive solubilization (Fig. 2.). The dissociation of azo dye-treated hetero- chromatin was clear in the electron micrographs (Fig. 3).

Amaranth was employed for the study of the release of nuclear proteins from the heterochromatin, as this dye has been using as a food additive in many countries. On the other hand, Ponceau 3R has been prohibited from use as a food additive because the azo dye has been associated with liver injury and tumor formation $^{11)}$. The results of SDS-polyacrylamide gel electrophoresis showed that non-histone proteins were released from amaranth-treated het- 


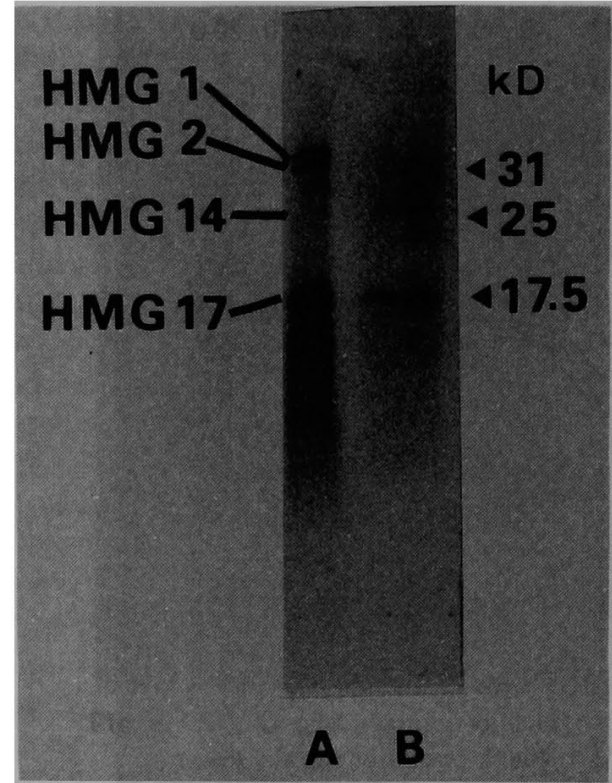

Fig. 6. Electrophoresis of the non-histone proteins released from $10 \mathrm{~m} M$ amaranthtreated heterochromatin and HMG proteins. (A), HMG proteins extracted from isolated rat-liver nuclei; (B), non-histone proteins released from $10 \mathrm{~m} M$ amaranth-treated heterochromatin.

erochromatin and histone proteins were not (Fig. 5). At a high concentration of amaranth, three kinds of chromosomal proteins were released from the heterochromatin. As we did not analyze the amino acid compositions of those proteins, a definite conclusion is not possible, but the proteins released from heterochromatin are presumed to be HMG proteins from their behavior on electrophoresis (Fig. 6). Although HMG proteins have been well-characterized, their function still remains unclear ${ }^{8)}$. It has been proposed that they might be involved in gene activation ${ }^{12}$.

In conclusion, our studies have shown that amaranth dissociates heterochromatin and releases non-histone proteins as well as HMG-like proteins from heterochromatin. A number of studies have revealed that non-histone proteins function as specific regulators of gene transcription in eukaryotic cells ${ }^{13}$. Therefore, modification of chromosomal proteins by the azo dyes might affect transcriptional regulation in the cell. However, in this experiment we could not show which chromosomal proteins were direct. ly concerned with the chromatin dissociation. Further work should be done to confirm the interaction between the azo dyes and histones, structural proteins of the nucleosome.

\section{References}

1) Weisbrod, S.: Nature 297, 289 295 (1982).

2) Yoshimoto, M., Yamaguchi, M., Hatano, S., Watanabe, T.: Fd Chem. Toxic. 22, 337 344 (1984).

3) Frenster, J. H., Allfrey, V. G., Mirsky, A. E.: Proc. Natl. Acad. Sci. U. S. A. 50, 1,026 1,032 (1963).

4) Yoshimoto, M., Suematsu, S., Hatano, S., Watanabe, T.: J. Food Hyg. Soc. Japan 20, 192 197 (1979).

5) Bradford, M. M.: Anal. Biochem. 72, 248 254 (1976).

6) Comings, D. E., Harris, D. C., Okada, T. A., Holmquist, G.: Exp. Cell Res. 105, 349 365 (1977).

7) Laemmli, U. K.: Nature 227, 680 685 (1970).

8) Inoue, A., Tei, Y., Hasuma, T., Yukioka, M., Morisawa, S.: FEBS Lett. 117, 68 72 (1980).

9) Rickwood, D., Hell, A., Malcolm, S., Birnie, G. D., MacGillivary, A. J.: Biochim. Biophys. Acta 353, 353 361 (1974).

10) Weintraub, H., Groudine, M.: Science 193, 848 856 (1976).

11) Hansen, H. H., Davis, K. J., Fitzhugh, O. G., Nelson, A. A.: Toxic. Appl. Pharmac. 5, 105 118 (1963).

12) Weisbrod, S., Groudine, M., Weintraub, H.: Cell 19, 289 301 (1980).

13) Peterson, J. L., McConkey, E. H.: J. Biol. Chem. 251, 548 554 (1976). 